\title{
AKTUALISASI MULTIPLE INTELLIGENCES PADA ANAK USIA 5-6 TAHUN MELALUI PERMAINAN OUTBOUND DI TAMAN KANAK-KANAK ISLAM PELANGI ANAK NEGERI YOGYAKARTA
}

\author{
Lukman $^{1}$ \\ Program studi Pendidikan Islam Anak Usia Dini (PIAUD) \\ Institut Agama Islam Muhammadiyah Bima \\ putrasanggar231@gmail.com
}

\section{Abstract:}

This research is titled the actualization of multiple intelligences in children aged 5-6 years through outbound games in the Rainbow Islamic Kindergarten of Yogyakarta State Children. With the aim of analyzing and knowing the results of developing the multiple intelligences approach. This research is expected to contribute positively to the development of Early Childhood learning, especially in multiple intelligences learning in outbound games for Early Childhood, as well as reference material for Rainbow Islamic Kindergarten, Yogyakarta Children and the wider community.

This type of research is research (field research), namely researchers conduct direct research on the object under study and data collection found in the field. This research includes the type of qualitative research, namely research that intends to understand the phenomenon of what is experienced by the subject of research such as behavior, perceptions, motivations, actions, and others. Data collection techniques were carried out by observing passive participation, through observation, interviews and documentation, and triangulation. After the data is obtained, it checks the validity of the data, analyzes the data with steps of data reduction, data presentation, conclusions, and verification of data. Development of outbound learning is designed so that children do not feel bored receiving learning in the classroom.

The results of the research findings are: first, children can explore and express multiple intelligence in each playing activity using four types of steps, namely; (a) at the time of environmental arrangement, (b) on the footing

${ }^{1}$ Lukman. M.Pd. Staf Pengajar pada Program Studi Pendidikan Islam Anak Usia Dini (PIAUD) Institut Agama Islam Islam Muhammadiyah Bima

Jurnal Pelangi Jurnal pemikiran dan penelitian pendidkan Islam anak Usia Dini 
before playing (circle time1), (c) during playing activities, (d) when stepping after playing (circle time 2 / recalling). Every outbound game always provides communication, counting, gesture, social, cooperation, naturalist, and moral values for children's development. Second, supporting factors in the actualization of multiple intelligences in Early Childhood Through Outbound Games include; a conducive Taman Kanak environment, creative teachers, game tools that are already available, then supplemented with adequate facilities and infrastructure. While the inhibiting factors in the actualization of multiple intelligences in Early Childhood through outbound games include; the absence of good cooperation between teachers and parents of students, community environment, family environment, the presence of social media, and technological sophistication, so that children are very difficult to monitor.

Keywords: Mulltiple Intelligence, Early Childhood, and Outbound Games

\section{A. PENDAHULUAN}

Dunia anak merupakan dunia yang diisi dengan hal yang menyenangkan salah satunya adalah bermain. Sesuai dengan perkembangan jaman, maka banyak pula permainan baru yang diciptakan untuk mengembangkan kreatifitas, pola pikir dan kecerdasan anak, seperti permainan untuk mengenalkan anak pada dunia teknologi, sains, alam dan lingkungan sosial. Setiap negara, tentu mempunyai berbagai macam permainan yang di mainkan oleh anak-anak baik di dunia pendidikan maupun lingkungan sosialnya, begitupun di negara Indonesia.

Pendidikan di Indonesia sendiri pada hakekatnya bertujuan untuk mencerdaskan kehidupan bangsa, dan setiap warga negara berhak mendapat pendidikan yang layak, hal ini tercantum dalam pembukaan Undang-Undang Dasar 1945 alinea keempat yang berbunyi: Kemudian dari pada itu untuk membentuk suatu pemerintah negara Indonesia yang melindungi segenap bangsa Indonesia dan untuk memajukan kesejahteraan umum, mencerdaskan kehidupan bangsa, dan ikut melaksanakan ketertiban dunia yang berdasarkan kemerdekaan, perdamaian abadi dan keadilan sosial. ${ }^{2}$

Pembelajaran dalam pendidikan Anak Usia Dini dilakukan dengan cara bermain sambil belajar. Pembelajaran dikemas sedemikian rupa agar

\footnotetext{
${ }^{2}$ Suyadi, \& Maulidha Ulfah, Konsep Dasar Paud, (Bandung: PT Rosdakarya, 2015), Cet ke-4, hlm.1.
} 
dapat memberikan suasana yang menyenangkan, memuaskan dan membekas. Pendidikan Anak Usia Dini merupakan pendidikan yang paling mendasar bagi pembentukan sumber daya manusia di masa mendatang.

Kualitas pendidikan Anak Usia Dini inilah yang nantinya akan menentukan kualitas sumber daya manusia di suatu negara. Semakin berkualitas pendidikan anak diusia dini, maka semakin berkualitas juga sumber daya yang akan dihasilkan generasi selanjutnya. Hal ini disebabkan karena masa usia dini merupakan ajang pembelajaran dan pembiasaan manusia dalam menghadapi tantangan hidup agar mampu bertahan dalam berbagai situasi. Bagian dari bentuk lembaga pendidikan Anak Usia Dini adalah Taman Kanak-kanak (TK).

Taman Kanak-kanak inilah diharapkan dapat ditanamkan dan dikembangkan berbagai potensi anak yang akan berguna bagi masa dewasanya. Hal ini juga tertuang dalam Kurikulum 2004 berbasis kompetensi mengenai tujuan pendidikan di Taman Kanak-kanak yaitu membantu anak didik dan mengembangkan berbagai potensi baik psikis dan fisik yang meliputi moral dan nilai-nilai agama, sosial emosional, kognitif, bahasa, fisik/motorik, kemandirian, dan seni untuk siap memasuki sekolah dasar. Usia Taman Kanak-kanak (berkisar antara 5-6 tahun) merupakan usia yang berada pada tahap egosentris dimana anak masih sangat kental dengan kelakuannya. ${ }^{3}$

Anak yang masih berada pada tahap ini sangat sulit untuk diajak berbagi dengan yang lain, selalu merasa dirinya lebih dari orang lain, dan sulit untuk diminta melakukan kegiatan dalam kelompok. Anak selalu menganggap apapun yang menjadi miliknya tidak boleh dibagi dengan orang lain, hanya ia seorang yang boleh memiliki. Berbagai cara dicari untuk menanamkan kebiasaan anak untuk bekerjasama agar nantinya dapat hidup bersosial sebagai anggota masyarakat.

Cara-cara yang dicari diusahakan menarik agar menyenangkan bagi anak dalam melakukannya. Cara yang menyenangkan merupakan cara yang dapat membuat anak aktif berpartisipasi dalam berbagai kesempatan aktivitas. Salah satu aktivitas yang dapat membuat anak senang dan tertarik adalah bermain. Bermain dapat dilakukan di luar dapat juga

\footnotetext{
${ }^{3}$ Ika Budi Maryatun, Pemanfaatan Kegiatan Outbound Untuk Melatih Kerjasama (Sebagai Moral Behavior) Anak Taman Kanak-Kanak, Jurnal. FIP UNY, Vol.12, Nomor.3, Mei 2011, hlm.6.
}

Jurnal Pelang̉i Jurnal pemikiran dan penelitian pendidkan Islam anak Usia Dini 
di dalam ruangan. Salah satu kegiatan bermain yang dapat digunakan untuk membiasakan kerjasama anak adalah melalui kegiatan outbound. Outbound dapat menstimulasi aspek fisik hingga psikis anak dengan berbagai aktivitas yang menyenangkan. ${ }^{4}$

Adapun pembelajaran yang mendukung bermain di luar ruangan (outdoor) yaitu pembelajaran di alam (outdoor education) yang dilakukan melalui permainan outbound. Outbound merupakan kegiatan bermain bagi Anak di alam terbuka yang dapat mendukung tiga jenis main (sensori, simbolik, dan pembangunan) dan dapat mengembangakan keterampilan sosial serta mengasah kecerdasan majemuk anak.

Outbound ini penggunaannya dinilai memberikan konstribusi positif terhadap kesuksesan belajar. Awalnya outbound ini dilakukan oleh orang Yunani kuno dan secara sistematis pendidikan melalui outbound dimulai di Inggris dengan membangun pendidikan berdasarkan petualangan (adventure based education) yang kemudian outbound ini dibangun di berbagai negara. Outbound menggunakan pendekatan belajar melalui pengalaman (experiential learning), karena pengalaman langsung terhadap sebuah kejadian membuat anak dengan mudah menyerap pengetahuan yang dialami sendiri.

Pemahaman anak terhadap suatu konsep hampir sepenuhnya tergantung pada pengalaman-pengalaman yang bersifat langsung (hands on experience)". Pendekatan bermain seperti ini, maka dapat menggugah emosional anak, anak dapat merasakan senang, takut, sukses (berhasil), atau gagal saat bermain, karena anak terlibat langsung secara aktif dalam mengembangkan aspek moral, dan nilai agama, bahasa, sosial emosi, fisik, kognitif, seni juga kecerdasan yang dimiliki anak. Sebagai contoh dalam permainan outbound terdapat jenis permainan jembatan dua utas tali (twoline bridge) yang mengembangkan aspek moral agama yaitu berdoa saat mengawali dan mengakhiri kegiatan, aspek sosial emosi yaitu melatih kesabaran selama menyelesaikan penyebrangan, aspek kognitif yaitu melatih konsentrasi dalam melakukan pekerjaan dan aspek fisik yaitu melatih keseimbangan.

${ }^{4}$ Wira Satya Indra, Membangun Kebugaran Jasmani dan Kecerdasan Melalui Bermain. (Jakarta: Depdiknas, Dirjen Dikti, Direktorat Ketenagaan, 2006), hlm.10. 
Pada dasarnya, pembelajaran outbound ini bertujuan untuk mengatasi anak-anak yang mengalami kesulitan dalam hubungan sosial, meningkatkan konsep diri anak-anak, mengembangkan kemampuan dan gagasan kreatif, tertantang untuk berperan aktif dengan memberanikan diri, terutama mengembangkan aspek motorik kasar anak. ${ }^{5}$ Pembelajaran outbound merupakan salah satu upaya dalam meningkatkan berbagai macam kecerdasan yang ada dalam diri seorang anak utama dari delapan kecerdasan yang ada dalam dirinya.

Anak relatif bebas melakukan berbagai hal dalam permainan yang dilakukannya. Tidak ada paksaan bagi anak harus melakukan sesuatu dalam bermain. Dalam bermain Anak melakukan berbagai kegiatan yang berguna untuk mengembangkan dirinya. Anak mengamati, mengukur, membandingkan, bereksplorasi, meneliti, dan masih banyak lagi yang dilakukan anak. Situasi seperti ini sering dilakukan tanpa disadari mereka telah melatih dirinya dalam beberapa kemampuan sehingga mereka memiliki kemampuan baru. ${ }^{6}$

Outbound adalah kegiatan di alam terbuka merupakan sarana penambah wawasan pengetahuan yang didapatkan dari serangkaian pengalaman berpetualangan sehingga dapat meningkatkan semangat dan kreatifitas seseorang. Kegiatan outbound berawal dari sebuah pengalaman sederhana seperti bermain. Bermain yang membuat anak dapat belajar menggali dan mengembangkan potensi dan rasa ingin tahu serta meningkatkan rasa percaya dirinya. Oleh Karena itu, bermain merupakan fitrah yang dialami oleh setiap anak. Pengalaman merupakan guru dalam proses pembelajaran secara alami. Hal itu dalam rangka mengembangkan pengetahuan dari setiap pengalaman. Jadi tidak menutup kemungkinan siapapun berhak bermain baik anak-anak, remaja, orang dewasa, ataupun orangtua.

Outbound merupakan perpaduan antara permainan sederhana, permainan ketangkasan dan olahraga serta diisi dengan petualangan-petualangan. Hal ini yang membuat adanya unsur-unsur ketangkasan dan kebersamaan serta keberanian dalam memecahkan masalah. Outbound

${ }^{5}$ Shela Kurnia, Pengembangan Kecerdasan Kinestetik Pada Anak Usia Dini Melalui Permainan Outbound di TK Model Sleman Yogyakarta, Jurnal Psikologi Undip Vol.6, No.2, Oktober 2010, hlm.3.

${ }^{6}$ Anita Yus, Penilaian Perkembangan Belajar Anak Taman Kanak-Kanak, (Jakarta: Kencana Prenada Media Group, Cetakan ke-1, 2011), hal..32.

Jurnal Pelang̉i Jurnal pemikiran dan penelitian pendidkan Islam anak Usia Dini 
sebagai permainan kecerdasan karena sebagai sarana untuk melatih dalam mengembangkan fungsi mata, telinga, dan latihan otot.

Bagi Anak Usia Dini permainan outbound dapat melatih dan memfokuskan diri dalam memecahkan masalah saat kegiatan berlangsung dan mewujudkan rasa percaya diri. Permainan outbound juga memberikan pengaruh dalam pengembangan kreatifitas dalam menentukan keputasan yang akan diambil. Misalnya anak autis menjadi lebih konsentrasi dalam mendengarkan setiap instruksi yang diberikan guru dalam setiap outbound. ${ }^{7}$

Taman Kanak-kanak Islam Pelangi Anak Negeri adalah Taman Kanak Unggulan yang menjadikan sebagai lembaga pendidikan anak yang unggul dan terkemuka di Daerah Istimewa Yogyakarta yang mengantarkan siswa menjadi anak yang kreatif, cakap, mandiri dan percaya diri.

Taman Kanak-Kanak Islam Pelangi Anak Negeri merupakan salah satu Taman Kanak yang menyelenggarakan program Pendidikan Anak Usia Dini yang profesional dan Islami. Selain itu, Taman Kanak-Kanak Islam Pelangi Anak Negeri menyelenggarakan layanan dan pencerahan bagi komunitas lingkungan Anak Usia Dini. Setiap hari sebelum masuk ke dalam ruangan untuk menerima pembelajaran, anak-anak dibiasakan untuk melakukan senam pagi kurang-lebih 15 menit, kebiasaan seperti ini diharapkan agar anak-anak membiasakan diri untuk hidup sehat. Kebiasaan ini dilakukan secara rutin sebelum anak-anak menerima pembelajaran di dalam kelas.

Taman Kanak-Kanak Islam Pelangi Anak Negeri juga memiliki keunikan tersendiri dalam melaksanakan proses pembelajaran. Sekali dalam sebulan mereka outbound atau belajar di alam terbuka sambil memperkenalkan apa yang ada di alam, guru-gurunya memfasilitasi mereka untuk bereksplorasi, guna untuk memperkenalkan mereka terhadap alam di sekitarnya, agar mereka dapat memupuk rasa cinta terhadap alam yang di amanahkan Allah SWT yang maha pencipta, dan mengembangkan dari semua aspek ke-9 kecerdasan yang dimilikinya baik itu berupa aspek kecerdasan verbal-linguistik, kecerdasan logika

\footnotetext{
${ }^{7}$ Muhammad Dzikron, Model-Model Permianan Outbound, (Klaten: Hizbul Wathan Organisasi Perpaduan Indonesia, 2016), hal.15.
} 
matematik, kecerdasan visual-spasial, kecerdasan musikal, kecerdasan kinestetik, kecerdasan interpersonal, kecerdasan intrapersonal, kecerdasan naturalis, maupun kecerdasan moral anak yang di tuangkan melalui berbagai macam permainan-permainan menantang yang dapat dikemas melalui permainan outbound. Dengan demikian peneliti tertarik meneliti tentang "Aktualisasi Multiple Intellegences Pada Anak Usia Dini Melalui Permainan Outbound di Taman Kanak-Kanak Islam Pelangi Anak Negeri Yogyakarta".

\section{B. METODE PENELITIAN}

Metodologi penelitian merupakan usaha seseorang yang dilakukan secara sistematis dengan mengikuti aturan-aturan penelitian guna menjawab permasalahan yang hendak diteliti. ${ }^{8}$

Jenis penelitian ini adalah penelitian (field research), yaitu peneliti mengadakan penelitian langsung terhadap objek yang diteliti dan dilakukan pengumpulan data yang ditemukan di lapangan. Penelitian ini termasuk jenis penelitian kualitatif, yaitu penelitian yang bermaksud untuk memahami fenomena tentang apa yang dialami oleh subjek penelitian misalnya perilaku, persepsi, motivasi, tindakan, dan lain-lain. Secara holistik, dan dengan cara deskripsi dalam bentuk kata-kata dan bahasa, pada suatu konteks khusus yang alamiah dan dengan memanfaatkan berbagai metode alamiah. Dengen cara mengumpulkan data yang berhubungan dengan aktualisasi multiple intellegences pada Anak Usia Dini melalui permainan outbound di Taman Kanak-Kanak Islam Pelangi Anak Negeri Yogyakarta. ${ }^{9}$

Penelitian ini dilaksanakan sejak tanggal 2 Februari s/d 3 April 2018, di Taman Kanak-Kanak Islam Pelangi Anak Negeri Yogyakarta.

Subjek dalam penelitian ini adalah siswa kelompok B usia 5-6 tahun di Taman Kana-Kanak Islam Pelangi Anak Negeri Yogyakarta yang berjumlah 25 orang. Dianataranya 10 orang anak laki-laki dan 15 orang anak perempuan.

\footnotetext{
${ }^{8}$ Agus Salim, Teori dan Paradigma Penelitian Sosial (Yogyakarta: Tiara Wacana, 2006), hal. 22.

${ }^{9}$ Syahirman Yusi \& Umiyati Idris, Metodelogi Penelitian Ilmu Sosial Pendekatan Kuantitatif, (Palembang: Citra Books Indonesia, 2009), hal. 103.
}

Jurnal Pelang̉i Jurnal pemikiran dan penelitian pendidkan Islam anak Usia Dini 
Prosedur penelitian yakni dengan memahami fenomena tentang apa yang dialami oleh subjek penelitian misalnya perilaku, persepsi, motivasi, tindakan, dan lain-lain. Secara holistik, dan dengan cara deskripsi dalam bentuk kata-kata dan bahasa, pada suatu konteks khusus yang alamiah dan dengan memanfaatkan berbagai metode alamiah. Dengan berbagai langkah-langkah yang ditempuh dalam kegiatan ini adalah seperti; menyiapkan istrumen wawancara, kemudian lembar observasi, dan lainlain yang mendukung dalam proses penelitian.

Pelaksanaan kegiatan outbound dilakukan oleh guru dan di bantu oleh peneliti sendiri. Guru menjadi mitra peneliti terlebih dahulu diberi pemahaman cara yang akan di mainkan oleh anak pada saat bermain outbound dialam terbuka.

Tekhnik Analisis data yang dipergunakan adalah suatu proses pengklasifikasian, pengkategorian, penyusunan, dan elaborasi, sehingga data yang telah terkumpul dapat diberikan makna untuk menjawab masalah penelitian. yang telah dirumuskan atau untuk mencapai tujuan penelitian. ${ }^{10}$

Berdasarkan jenis penelitian yang bersifat kualitatif, maka analisa data berlangsung pada saat pengumpulan data. Proses analisis mengalir dari tahap awal hingga tahap penarikan kesimpulan hasil studi. ${ }^{11}$

\section{HASIL DAN PEMBAHASAN}

Hasil temuan penelitian adalah bahwa Taman Kanak-Kanak Islam Pelangi Anak Negeri Yogyakarta mengadakan outbound selama satu kali dalam sebulan, tepat pada hari sabtu 10 februari 2018, mulai dari jam 07.30-13.30. Ada beberapa jenis permainan yang diterapkan oleh guru yang berkaitan dengan Sembilan aspek kecerdasan yang ada dalam diri anak. Sembilan kecerdasan yang di maksud adalah:

1. Kecerdasan Verbal Linguistik

Pada saat guru mengadakan outbound, guru menerapkan permainan menirukan bunyi untuk mengasah kecerdasan verbal linguistik pada anak didiknya. Permainan ini mengajak peserta didik menggunakan

\footnotetext{
${ }^{10}$ Suharsimi Arikunto, Prosedur Penelitian Suatu Pendekatan Praktek, (Jakarta: Rineka Cipta, 1997), hal.34.

${ }^{11}$ Sugiyono, Metode Penelitian Pendidikan (Bandung: Alfabeta, 2011), hal.338.
} 
suara-suara binatang untuk menentukan identitas-identatis mereka. Kerena para peserta perlu semakin akrab satu dengan yang lain untuk mengetahui nama masing-masing peserta.

Dimana pada saat melaksanakan kegiatan tersebut. Dari 21 anak didiknya terdapat 5 anak laki-laki dan 9 anak perempun. Kemudian sisanya lebih memilih pasif dan bahkan melakukan permainan yang cenderung lebih kepada hobinya masing-masing.

Dari permainan tersebut guru menyuruh anak didik untuk memprakkan suara berbagai jenis binatang, diantaranya suara burung, kemudian suara kucing, suara kerbau, dan suara kambing. Dari suara-suara tersebut 5 anak laki-laki mampu menirukan suara kucing, dan suara kambing, kemudian 9 anak perempuan mampu menirukan suara binatang. Hal ini sejalan dengan pernyataan Umi Sri Utami Purwaningsih selaku Pembina Taman Kanak-Kanak tersebut, beliau menjelaskan bahwa:

"Dengan mempraktekan berbagai macam jenis suara binatang saat melakukan outbound tujuan adalah agar anak bisa mengetahui bagaimana suara-suara binatang saat hidup di alam bebas. Selain itu juga dapat mengembangkan daya imajinasi anak dalam menirukan berbagai macam jenis suara binatang". ${ }^{12}$

2. Kecerdasan logika matematik

Pada saat yang bersamaan ketika mengadakan permainan outbound, guru juga mengadakan permainan yang mengasah kecerdasan matematik melalui sedikit-banyak. Permainan ini bertujuan untuk mengenalkan hitungan kepada anak didiknya, agar mereka paham dan mengenal angka.

Cara melakukan permainan ini, semua anak di perintahkan untuk melihat alat yang sudah dibuat dan dibagikan porsi banyak dan sedikitnya. Kemudian mereka di suruh memindahkan dan mengambil alat-alat itu untuk di masukkan ke dalam botol sambil menghitung. Hasil yang peneliti temukan ketika anak mempraktekan permainan tersebut bahwa terdapat 6 orang anak laki-laki yang pintar menghitung, sedangkan dari 8 anak perempuan yang pandai meng-

${ }^{12}$ Hasil wawancara dengan umi Sri Utami Purwaningsih pada tanggal 10 Februari 2018, jam 08.15 WIB.

Jurnal Pelang̉i Jurnal pemikiran dan penelitian pendidkan Islam anak Usia Dini 
hitung, dan sisanya pasif. Hal ini sejalan dengan pernyataan Umi Isti Ratnaningsih selaku guru pendamping outbound, dia menjelaskan bahwa:

"Selain dari mengasah kemampuan verbal-linguistiknya juga dapat mengembangkan daya menghitung anak, karena dalam permainan ini anak memang benar-benar ajarkan untuk memahami angka-angka" ${ }^{13}$

Pernyataan hampir sama juga disampaikan oleh Umi Purdiningtyas Kusumastuti, bahwa:

"Selain mengasah kemampuan verbal-linguistik dan kecerdasan matematiknya, anak-anak-anak dilatih untuk lebih memahami cara bermain, karena pada intinya permainan itu, akan memberikan nilai yang positif terhadap perkembangan anak". ${ }^{14}$

Jadi dari kedua pendapat diatas, peneliti dapat menyimpulkan bahwa: permainan sedikit banyak, bisa membantu mereka untuk mengenal dan mengasah kemampuan berpikir.

3. Kecerdasan Visual-Spasial

Permainan menggambar, menggambar bisa mengasah kreatifitas anak. Jika ia tidak terbiasa dan tidak pernah melatih kemampuan untuk menggambar, ia akan sama dengan orang lain. Seragam, karena terbiasa meniru. Aktivitas menggambar dan mewarnai menjadi saran anak untuk mengekspresikan dirinya sendiri dengan gambar yang ia sukai. Misalnya, menggambar dua buah gunung dangan matahari di bagian tengah.

"Ada banyak manfaat yang dapat diperoleh lewat aktivitas menggambar seperti: melatih gerak tangan untuk menghasilkan bentuk agar gambar yang lebih baik, kemudian, membnatu anak dalam meningkatkan konsentrasi, melatih daya ingat, melatih kesabaran, ketelitian dan keuletan anak dalam menghasilkan sesuatu." Tutur umi Ninik Indarsih. ${ }^{15}$

Berdasarkan pendapat diatas, dapat ditarik sebuah kesimpulan bahwa dalam permainan menggambar anak bisa melatih dan

\footnotetext{
${ }^{13}$ Hasil wawancara dengan umi Isti Ratnaningsih pada tanggal 10 Februari 2018, jam 08.20 WIB.

${ }^{14}$ Hasil wawancara dengan Umi Purdiningtyas Kusumastuti pada tanggal 10 februari 2018, jam 08.25 WIB.

${ }^{15}$ Hasil wawancara dengan umi Ninik Indarsih pada tanggal 10 Februari 2018, jam 08.32 WIB.
} 
merangsang konsentrasi dan ketahanan mental terhadap lingkungan, selain itu juga dapat melatih gerak tangan anak pada saat anak menggambar.

4. Kecerdasan Musik

Kecerdasan ini merupak kemampuan memahami, membedakan dan mengubah dan mengungkapkan bentuk-bentuk musikal. Kecerdasan ini meliputi kepekaan pada irama , pola titik nada dan melodi, kemudian suara lagu. Contoh permainan yang diterapkan pada saat itu adalah permainan mendengarkan lagu atau music, seperti pernyataan umi Siti Nur Amanah:

"Musik dapat membantu anak dalam merangsang daya ingat anak, karena musik merupakan salah satu sarana komunikasi bagi anak yang masih keterbatasan dalamberkomunikasi, untukitu pengenalan musik berpengaruh cukup besar terhadap perkembangan memori dan perhatian anak terhadap lingkungan sekitarnya". ${ }^{16}$

5. Kecerdasan Kinestetik

Kecerdasan kinestetik adalah kemampuan untuk menggunakan kecakapan tubuh untuk mengatasi masalah, untuk menghasilkan, menggunakan tubuh secara terampil untuk mengungkapkan ide, pemikiran dan perasaan.

Permainan yang di terapkan pada saat itu adalah permainan meniru gerakan. Pada permainan ini, anak-anak juga dapat mengembangkan semua potensinya secara optimal, baik potensi fisik yang berhubungan dengan kecerdasan gerak-kinetetik, mental intelektual dan spiritual.

Oleh karena itu, Anak Usia Dini merupakan jembatan berkembangnya semua aspek. Adapun manfaat dari permainan ini, anak menjadi lebih kreatif, kemudian dapat digunakan sebagai terapi kepada anak. Seperti halnya di ungkapkan oleh umi Retnowati:

"Melalui Permainan ini anak akan bisa menggerakkan sebagian anggota tubuhnya, dapat merangsang dengan cepat dan bahkan bisa mengikuti atau dapat meniru langsung apa yang diajarkan oleh gurunya, tampa di perintah mereka sudah bisa dan langsung mem-

${ }^{16}$ Hasil wawancara dengan umi Siti Nur Amanah pada tanggal 10 februari 2018, jam 09.10 WIB.

Jurnal Pelang̉i Jurnal pemikiran dan penelitian pendidkan Islam anak Usia Dini 
praktekkannya, walaupun masih ada anak yang belum sepenuhnya bisa". ${ }^{17}$

Permainan gerak dan lagu atau menari, bermanfaat bagi anak untuk mengembangkan kelenturan tubuh anak. Untuk Anak Usia Dini bermain ini dapat dilakukan dengan gerakan-gerakan yang sederhana dengan tidak meninggalkan unsur gerak dan seninya. Disamping itu juga ada beberapa permainan yang dapat mengembangkan kemampuan motorik kasar anak, antara lain: bermain ayunan, jungkat-jungkit, plosotan, panjat-panjatan, gobag sodor, bermain sepeda, dan lain-lain.

6. Kecerdasan Interpersonal

Kecerdasan yang melibatkan kemampuan memahami dan berkomunikasi dengan orang lain, serta melihat perbedaan orang lain dari segi suasana hati, temperamen dan motivasi. Anak dengan kecerdasan interpersonal yang menonjol, cenderung lebih baik dan mudah menjalin interaksi sosial, serta sangat sensitif terhadap perasaan orang lain. Selain itu, dia juga berpeluang menjadi pemimpin di kelompoknya.

Jenis permainan yang diterapkan yaitu permainan mendengarkan mereka berbicara, bercerita, mengungkapkan perasaan dan pikirannya. Dalam permainan ini anak dapat mengembangkan kecerdasan interpersonal, misalnya dengan berbicara tentang perasaan Anda atau orang lain.

Katakan padanya, "Nenek sedang sedih, Nak. Jadi, jangan dulu mengajaknya bermain boneka ya." Anak bisa menjadi pengajar, pekerja sosial, konselor, politisi, atau mediator. Kemudian bacakan buku cerita favorit anak. Tanyakan padanya apa yang dirasakan oleh karakter dalam cerita dan mengapa si tokoh merasa demikian. Seperti di jelaskan oleh umi Suwarti bahwa:

"Memang betul sekali ya..., kalau kita membiasakan anak dalam bercerita, maka anak dengan sendiri menggunakan daya nalarnya dalam bercerita, karena pada masa itu anak banyak bertanya tentang suatu hal, walaupun mereka belum sepenuhnya paham tentang apa

${ }^{17}$ Hasil wawancara dengan umi Retnowati pada tanggal 3 Maret 2018, jam 08.15 WIB. 
yang di katakan, tapi inilah keunikan anak. Pada usia itu mereka lebih aktif bertanya kepada orang-orang yang ada di sekitarnya". ${ }^{18}$

7. Kecerdasan Intrapersonal

Kecerdasan yang melibatkan kemampuan memahami diri sendiri, mengetahui siapa dirinya, apa yang ingin ia lakukan, bagaimana reaksi diri terhadap suatu situasi, dan memahami situasi seperti apa yang sebaiknya dihindari. Beberapa ciri anak dengan kecerdasan intrapersonal di atas rata-rata adalah tahu apa yang dapat dan tidak dapat dilakukan dalam lingkungan sosial, dan tahu siapa orang yang tepat untuk dimintai bantuan.

Permainan yang di terapkan adalah jenis permainan mengajak berimajinasi menjadi tokoh sebuah cerita. Dalam permainan ini anak di suruh untuk menghayal bebas dan berimajinasi terkait dengan apa yang ada dalam pikiran mereka sendiri. Anak di suruh menggambar sesuatu yang bisa ada pikiran mereka dengan bebas, dan apa yang dimereka gambar itu akan bisa kita baca seperti apa yang terlihat pada gambar tersebut:

“Apa yang dilakukan dalam permainan itu, akan mampu menstimulasi daya imajinasi anak. Itu juga merupakan upaya untuk menstimulasi, menumbuhkan dan meningkatkan potensi kecerdasan juga kreativitas di masa pertumbuhannya. Imajinasi anak berkembang seiring dengan berkembangnya kemampuan ia berbicara dan berbahasa. Seperti bermain, dunia imajinasi juga merupakan dunia yang sangat dekat dengan dunia anak. Imajinasi anak merupakan sarana untuk mereka berselancar dan belajar memahami realitas keberadaan dirinya juga lingkungannya. Karena itu, orang tua dapat mengembangkan imajinasi anak dengan menstimulasi tumbuh kembangnya potensi dan kemampuan imajinatif anak untuk diekspresikan dengan efektif". Tutur umi Yunani. ${ }^{19}$

Kemudian senada dengan penjelasan umi Asmihartutik terkait dengan permainan tersebut, dia menjelaskan bahwa:

"Anak di biasakan untuk dilatih imajinasi dan daya nalarnya, supaya mereka lebih aktif dan cepat menangkap setiap apa yang diajarkan

${ }^{18}$ Hasil wawancara dengan umi Suwarti pada tanggal 3 Maret 2018, jam 08.19 WIB.

${ }^{19}$ Hasil wawancara dengan umi Yunani pada tanggal 3 Maret 2018, jam 08.25 WIB.

Jurnal Pelang̉i Jurnal pemikiran dan penelitian pendidkan Islam anak Usia Dini 
oleh gurunya. Dan biasanya anak seperti itu akan terlihat aktif pada saat guru mengajar, dan biasanya mereka juga banyak bertanya dan lebih aktif dalam ruangan" ${ }^{20}$

8. Kecerdasan Naturalis

Kecerdasan naturalis adalah keahlian dalam mengenali dan mengklasifikasikan berbagai spesies flora dan fauna, dari sebuah lingkungan. Intinya adalah kemampuan manusia untuk mengenali tanaman, hewan, dan bagian lain dari alam semesta. Kecerdasan ini tepat untuk membantu dalam memahami pelajaran biologi dengan mudah.

Salah satu permainan yang dilakukan yaitu permainan mengamati alam di sekitarnya, tujuan dari permainan ini anak di perkenal berbagai macam jenis tumbuhan yang ada di alam, misalnya tumbuh-tumbuhan, binatang dan apa saya yang ada di sekitarnya. Hal ini dijelaskan oleh umi Surojo, beliau menjelaskan makna dari apa yang mereka lakukan itu. Menurut beliau:

"Adanya permainan seperti ini, agar anak-anak bisa mengenal bergabai jenis ciptaan Allah misalnya: tumbuhan-tumbuhan, binatang, dan lain-lain sebagainya. Dari apa yang mereka amati itu, mereka mampu mencerikan kepada teman-temannya. Ini semua sebagai untuk memperkaya pengetahuan anak" ${ }^{21}$

9. Kecerdasan Moral

Kecerdasan moral atau yang biasa dikenal dengan moral quotient (MQ) adalah kemampuan seseorang untuk membedakan mana yang benar dari mana yang salah akan etika dan menerapkannya dalam tindakan. Seperti: empati, hati nurani, kontrol diri, rasa hormat, kebaikan hati, toleransi dan keadilan. Pertumbuhan moral merupakan suatu proses yang terus-menerus berkelanjutan sepanjang hidup dan selama itu pula banyak hal lain yang diserapnya, bahkan ahli moralitas melihat ada lebih dari empat ratus kebajikan.

Permainan yang di terapkan yaitu permainan menghargai orang lain. Permainan ini bertujuan untuk memberikan pengetahuan pada anak, agar mereka lebih menghargai orang-orang yang di sekitar

\footnotetext{
${ }^{20}$ Hasil wawancara dengan umi Asmihartutik pada tanggal 3 Maret 2018, jam 09.12 WIB.

${ }^{21}$ Hasil wawancara dengan umi Sarojo pada tanggal 3 Februari 2018, jam 09-21 WIB.
} 
mereka. Terutama bapak, mama, dan saudara-saudaranya. Apa yang dilakukan oleh mereka itu berdampak positif terhadap prilaku mereka. Seperti halnya ungkapan umi Sri Ratna Rahayu, beliau mengatakan:

"Perlu ada kegitan seperti ini, agar anak nanti bisa menghargai dan menghormati teman-temannya, terutama orang tuanya. Anak biasanya akan terbiasa apa sering diajarkan dengan hal-hal yang positif, karena anak merespon apa yang mereka dengar dan meraka lihat" ${ }^{22}$ Multiple Intelegences adalah kemampuan untuk melakukan abstraksi, serta berpikir logis dan cepat sehingga dapat bergerak dan menyesuaikan diri terhadap situasi yang baru. Multiple Intelegences secara umum dipahami pada dua tingkat yakni: Pertama, Kecerdasan sebagai suatu kemampuan untuk memahami informasi yang membentuk pengetahuan dan kesadaran. Kedua, Kecerdasan sebagai kemampuan untuk memproses informasi sehingga masalah-masalah yang kita hadapi dapat dipecahkan (problem solved) dan dengan demikian pengetahuan pun akan bertambah.

"Gardner berpendapat bahwa kecerdasan setiap Anak tentu berbeda-berbeda. Apabila seorang anak tidak cerdas di satu bidang, bisa jadi ia cerdas di bidang yang lain. Tentu ada yang menonjol dari tiap anak bila dilihat dari sembilan aspek kecerdasan dalam diri seorang anak kelak, namun sebagai orang tua kita berusaha untuk mengembangkan kesembilannya pada saat usia balita. Diantara kecerdasan yang dimaksud oleh howerd Gardner adalah kecerdasan verbal-linguistik, matematis-logis, visual-spasial, musikal, kinestetik, interpersonal, intrapersonal, naturalis, dan kecerdasan moral. ${ }^{23}$

\section{KESIMPULAN}

Kesimpulan yang diambil dalam penelitian ini adalah: mengenai aktualisasi multiple intelligences pada anak usia 5-6 tahun melalui permain outbound di Taman Kanak-Kanak Islam Pelangi Anak Negeri Yogyakarta

\footnotetext{
${ }^{22}$ Hasil wawancara dengan umi Sri Ratna Rahayu selaku orang tua siswa tada tanggal 3 Maret 2018, jam 10.30.

${ }^{23}$ Howard Gardner, Multiple Intelligences The Theory In Practice, (New York: Basic Books 1993), hlm.8.
}

Jurnal Pelang̉i Jurnal pemikiran dan penelitian pendidkan Islam anak Usia Dini 
adalah dapat memberikan nilai positif terhadap perkembangan anak. Melalui permainan outbound anak dapat meningkatkan kecerdasannya. Dimana anak dengan sendirinya mengasah kemampuan mereka dalam berbagai macam kegiatan di sekolah.

\section{DAFTAR PUSTAKA}

Arikunto Suharsimi, Prosedur Penelitian Suatu Pendekatan Praktek, Jakarta: Rineka Cipta, 1997.

Dzikron Muhammad, Model-Model Permianan Outbound, Klaten: Hizbul Wathan Organisasi Perpaduan Indonesia, 2016.

Gardner Howard, Multiple Intelligences The Theory In Practice, New York: Basic Books 1993.

Hasil wawancara dengan umi Sri Ratna Rahayu selaku orang tua siswa tada tanggal 3 Maret 2018, jam 10.30

Hasil wawancara dengan umi Sarojo pada tanggal 3 Februari 2018, jam 09-21 WIB.

Indra Satya Wira, Membangun Kebugaran Jasmani dan Kecerdasan Melalui Bermain. Jakarta: Depdiknas, Dirjen Dikti, Direktorat Ketenagaan, 2006.

Kurnia Shela, Pengembangan Kecerdasan Kinestetik Pada Anak Usia Dini Melalui Permainan Outbound di TK Model Sleman Yogyakarta, Jurnal Psikologi Undip Vol.6, No.2, Oktober 2010.

Maryatun Budi Ika, Jurnal, Pemanfaatan Kegiatan Outbound Untuk Melatih

Kerjasama (Sebagai Moral Behavior) Anak Taman Kanak-Kanak, FIP UNY, Vol.12, Nomor.3, Mei 2011.

Salim Agus, Teori dan Paradigma Penelitian Sosial, Yogyakarta: Tiara Wacana, 2006.

Sugiyono, Metode Penelitian Pendidikan (Bandung: Alfabeta, 2011), hlm.338. Suyadi, \& Ulfah Maulidha, Konsep Dasar Paud, Bandung: PT Rosdakarya, 2015.

Yus Anita, Penilaian Perkembangan Belajar Anak Taman Kanak-Kanak, Jakarta: Kencana Prenada Media Group, Cetakan ke-1, 2011.

Yusi Syahirman \& Idris Umiyati, Metodelogi Penelitian Ilmu Sosial Pendekatan Kuantitatif, Palembang: Citra Books Indonesia, 2009. 